\title{
Ocorrência da mancha-bacteriana do feijão-caupi em Roraima e reação de cultivares
}

\author{
Bernardo de Almeida Halfeld-Vieira ${ }^{1}$, Kátia de Lima Nechet ${ }^{1}$, Giovanni Ribeiro de Souza ${ }^{2}$
}

${ }^{1}$ Embrapa Meio Ambiente, SP 340, km 127,5, CP 69, 13820-000, Jaguariúna-SP; ${ }^{2}$ Embrapa Roraima, BR 174, km 8, CP 133, 69301-970, Boa

Vista-RR.

Autor para correspondência: Bernardo Almeida Halfeld-Vieira (halfeld@ cnpma.embrapa.br)

Data de chegada: 06/09/2010. Aceito para publicação em: 25/01/2011.

1695

\section{RESUMO}

Halfeld-Vieira, B.A.; Nechet, K.L.; Souza, G.R.. Ocorrência da mancha-bacteriana do feijão-caupi em Roraima e reação de cultivares. Summa Phytopathologica, v.37, n.3, p.127-130, 2011.

A mancha-bacteriana, causada por Xanthomonas axonopodis pv. vignicola, é uma doença que apresenta potencial de dano à cultura do feijão-caupi. Esse trabalho teve como objetivos registrar a ocorrência do patógeno em Roraima e prover informações sobre a reação de cultivares de feijão-caupi à doença. As cultivares utilizadas foram BRS-Amapá, BR02-Bragança, BRS Guariba, BR17-Gurguéia, BRS Mazagão, BRS Milênio, BRS Patativa, Pitiúba, BR03-Tracuateua e Vita-7. Em casa-de-vegetação, o delineamento experimental utilizado foi inteiramente casualizado, com quatro repetições, cada repetição foi representada por duas plantas/vaso. Os parâmetros de avaliação foram período de incubação e severidade da doença aos 25 dias após a inoculação. O experimento de campo foi conduzido em delineamento de blocos ao acaso com 4 blocos, sendo cada um constituído por 10 parcelas, sendo cada parcela semeada com uma cultivar. As inoculações foram realizadas aos 35 dias após a semeadura, em estádio de início da emissão do botão floral. Os parâmetros avaliados foram período de incubação, severidade da doença aos 12, 18, 22, 27 e 29 dias após a inoculação. A transmissibilidade da bactéria por meio de sementes foi verificada a partir da deposição em placas de Petri contendo o meio 523 de alíquotas de $100 \mu 1$ de suspensões obtidas de diluições seriadas em fator 1:10 de $150 \mathrm{~g}$ de sementes de cada lote. Verificou-se que as cultivares BRS Mazagão, BR 17- Gurguéia e Vita-7 apresentaram reação de resistência à mancha-bacteriana. Não foi verificada a ocorrência da transmissibilidade da bactéria nas condições experimentais.

Palavras-chave adicionais: Vigna unguiculata, Xanthomonas axonopodis pv. vignicola, Xanthomonas campestris pv. vignicola, resistência.

\section{ABSTRACT}

Halfeld-Vieira, B.A.; Nechet, K.L.; Souza, G.R. Report of cowpea bacterial blight in Roraima and reaction of cultivars. Summa Phytopathologica, v.37, n.3, p.127-130, 2011.

Bacterial blight, caused by Xanthomonas axonopodis pv. vignicola, is a disease that has the potential to cause damage to cowpea crops. The aims of this work were to report the occurrence of such a pathogen in Roraima State, Brazil, and provide information about the reaction of cowpea cultivars to that disease. The used cultivars were BRS-Amapá, BR02-Bragança, BRS Guariba, BR17-Gurguéia, BRS Mazagão, BRS Milênio, BRS Patativa, Pitiúba, BR03-Tracuateua and Vita-7. The study was carried out in a greenhouse in a completely randomized experimental design, with four replicates, each one represented by two plants per pot. Incubation period and disease severity were evaluated at 25 days post-inoculation. The field experiment was carried out in an experimental design of randomized blocks with four blocks, each one represented by 10 plots, and each plot was sown with one cultivar. Inoculations were performed at 35 days after sowing, at the beginning of flower bud emission. Evaluation parameters consisted of incubation period, disease severity at 12,18 , 22, 27 and 29 days post-inoculation and bacterial transmissibility through seeds. The cultivars BRS Mazagão, BR 17- Gurguéia and Vita7 presented resistance reaction to bacterial blight. No bacterial transmissibility was detected under these experimental conditions.

Keywords: Vigna unguiculata, Xanthomonas axonopodis pv. vignicola, Xanthomonas campestris pv. vignicola, resistance.

A cultura do feijão-caupi [Vigna unguiculata (L.) Walp.] é uma das mais importantes nas regiões tropicais do continente africano e do norte e nordeste brasileiro, como fonte de renda e de aminoácidos essenciais para a população $(4,20)$. Entretanto, problemas fitossanitários como a mela, causada pelo fungo Rhizoctonia solani Kühn [Thanatephorus cucumeris (Frank) Donk], podem ser limitantes à cultura em condições favoráveis à ocorrência de epidemias (13). No Brasil, a mancha-bacteriana do feijão-caupi causada por Xanthomonas axonopodis pv. vignicola (Burkholder 1944) Vauterin, et al., 1995 tem ocorrência relatada somente nos estados do Ceará e Piauí (11) sendo considerada uma doença que causa poucos danos à cultura, porém ainda há poucas informações sobre este patossistema no país, o que pode ser atribuído à restrita incidência da doença (4). Entretanto, a mancha-bacteriana apresenta grande potencial de dano, que é influenciado pelas condições da região, o sistema de cultivo e à época de plantio (3). Em países onde o feijão-caupi é tradicional e cultivado de forma mais intensiva, a mancha-bacteriana constitui uma das principais doenças da cultura, podendo ocasionar considerável redução na produção $(14,16)$, havendo dados de que a doença pode ocasionar epidemias severas, com 70 a $90 \%$ de incidência (12) e causar significativa redução na produção $(3,14)$ podendo atingir índices próximos a $92 \%$ (8). 
Não existe um método eficiente para o controle da manchabacteriana do feijão-caupi, sendo recomendado o uso de variedades resistentes, plantio em áreas livres do patógeno e uso de sementes sadias (4). A principal medida de controle preconizada para esta doença é a identificação de genótipos resistentes, por ser considerado de baixo custo e com boa aceitação pelos produtores (14). Neste contexto, o objetivo deste trabalho foi assinalar a ocorrência do patógeno no estado de Roraima e prover informações sobre a reação de cultivares de feijãocaupi cultivadas no Brasil à mancha-bacteriana, ampliando as alternativas de medidas de controle da doença e auxiliando na identificação de fontes de resistência à doença para programas de melhoramento.

\section{MATERIAL E MÉTODOS}

\section{Obtenção e identificação do isolado bacteriano}

Em setembro de 2006, em plantios estabelecidos na cidade de Boa Vista, Roraima, foram observadas plantas de feijão-caupi das cultivares BRS-Amapá, Pitiúba e BR02-Bragança, apresentando manchas foliares necróticas com exsudação bacteriana, frequentemente com halo amarelado, iniciando, na maioria das vezes, a partir dos bordos, de onde se procedeu o isolamento da bactéria, em meio 523 (6). A identificação do agente causal foi realizada por meio das características da colônia, teste de Gram, produção de xantomonadina, oxidase, urease, hidrólise do amido e aesculina, ácido a partir de arabinose e utilização de D-frutose, Lfucose, D-manose, manitol, melibiose, glicerol, glicose, sacarose, D-trealose, asparagina, dulcitol, arginina e sorbitol como fontes únicas de carbono e nitrogênio $(7,10,12,17)$.

Para realização de testes de patogenicidade e gama de hospedeiros, foram cultivadas dez plantas de feijão-caupi das cultivares Pitiúba e BR02-Bragança, de soja (Glicine max L. Merr.) cv. Tracajá e feijão-comum (Phaseolus vulgaris L.) var. Carioca que, após 15 dias da semeadura, foram pulverizadas com uma suspensão bacteriana, em uma concentração previamente ajustada a $5 \times 10^{7} \mathrm{ufc} / \mathrm{mL}$, mantendo-se em câmara úmida por $24 \mathrm{~h} \mathrm{e}$, posteriormente, em casa-de-vegetação. Estes ensaios foram repetidos três vezes. Para verificação de reação de hipersensibilidade (HR), plantas de fumo foram infiltradas com a mesma suspensão utilizada para as inoculações.

\section{Ensaio em casa-de-vegetação}

Foram avaliadas as cultivares: BRS-Amapá, BR02-Bragança, BRS Guariba, BR17-Gurguéia, BRS Mazagão, BRS Milênio, BRS Patativa, Pitiúba, BR03-Tracuateua e Vita-7, recomendadas para plantio a produtores de feijão-caupi nas regiões norte e nordeste. A suspensão bacteriana foi obtida por crescimento da cultura em meio 523 (6) por $48 \mathrm{~h}$ a $25^{\circ} \mathrm{C}$, seguido da adição de solução de cloreto de sódio a $0,85 \%$ e ajuste da concentração bacteriana a $5 \times 10^{7} \mathrm{ufc} / \mathrm{mL}$. O delineamento experimental utilizado foi o inteiramente casualizado, com quatro repetições, em que cada repetição foi representada por duas plantas cultivadas em um vaso plástico, com capacidade para 1,5 L. A avaliação do período de incubação foi realizada pela observação do período decorrido entre a inoculação e a visualização dos sintomas e, para severidade da doença aos 25 dias após a inoculação, foram quantificados os percentuais de área foliar lesionada com auxílio de escala diagramática elaborada para avaliação do crestamento bacteriano do feijoeiro comum (5), doença que apresenta sintomas semelhantes ao da manchabacteriana do feijão-caupi.

\section{Ensaio em condições de campo}

O experimento de campo foi conduzido no período de 19/7/2007 a 21/9/2007 em área localizada na sede da Embrapa Roraima. O delineamento utilizado foi o de blocos ao acaso com 4 blocos, sendo cada um constituído por 10 parcelas. As parcelas foram implantadas com dimensões de 2,0 x 5,0 m, com 4 linhas de plantio em espaçamento de $0,50 \mathrm{~m}$ e entre plantas de $0,25 \mathrm{~m}$, sendo cada parcela semeada com uma cultivar, utilizando-se as mesmas do ensaio em casa-de-vegetação. As inoculações foram realizadas aos 35 dias após o semeio, em estádio de início da emissão do botão floral. A suspensão bacteriana foi obtida e ajustada da mesma forma descrita para o ensaio em casa-de-vegetação. As plantas foram inoculadas ao final da tarde, após ter sido registrada precipitação pluviométrica de $40 \mathrm{~mm}$ (Figura 1), por pulverização de $1,1 \mathrm{~L}$ da suspensão bacteriana em cada parcela, utilizando-se pulverizador costal. As avaliações dos períodos de incubação foram realizadas observando-se o período decorrido entre a inoculação e a visualização dos primeiros sintomas. A quantificação da severidade da doença foi realizada aos 12, 18, 22, 27 e 29 dias após a inoculação, por meio da escala diagramática utilizada para avaliação da severidade em casa-de-vegetação (5), estimando-se o percentual de área foliar lesionada em cada período. A partir dos dados de severidade calculou-se a área abaixo da curva de progresso da doença (AACPDcmp) (2).

\section{Análises estatísticas}

Para as análises estatísticas foi utilizado o programa SAS, versão 9, através do comando proc GLM. O contraste de médias foi obtido por teste de Tukey $(\mathrm{p} \leq 0,05)$.

\section{Transmissibilidade pelas sementes}

As sementes obtidas das plantas utilizadas no experimento em condições de campo foram utilizadas para avaliação da transmissibilidade da bactéria pelas sementes. De cada lote obtido em uma parcela foram utilizados $150 \mathrm{~g}$ de sementes, imersas em $400 \mathrm{ml}$ de soluçăo estéril de $\mathrm{MgSO}_{4}$ a $0,01 \mathrm{M}$, por $12 \mathrm{~h}$ a $18{ }^{\circ} \mathrm{C}$. Decorrido este período, a solução foi filtrada em gaze e submetida à centrifugação $2262 \mathrm{~g}$ por $20 \mathrm{~min}$. O sobrenadante foi descartado e o pellet obtido ressuspendido em $5 \mathrm{ml}$ de solução estéril de $\mathrm{MgSO}_{4}$ a $0,01 \mathrm{M}$, realizando-se diluição seriada em fator 1:10 (21). Foram utilizadas para semeio, as diluições $10^{-4}, 10^{-5}, 10^{-6}$, determinadas em testes preliminares como sendo as que permitem melhor visualização de colônias isoladas, considerando as bactérias associadas às sementes. Em cada placa contendo o meio 523 (6) foi depositada uma alíquota de $100 \mu 1$ de uma das suspensões, procedendo-se ao espalhamento com alça de Drigalski. Para cada diluição foram utilizadas 3 repetições, incubando-se o material à $25{ }^{\circ} \mathrm{C}$ por até 10 dias, para verificação da presença de colônias típicas de $X$. axonopodis pv. vignicola.

\section{RESULTADOS E DISCUSSÃO}

Os testes de patogenicidade e gama de hospedeiros permitiram verificar que os sintomas da mancha-bacteriana foram observados apenas nas plantas de feijão-caupi, reisolando-se o patógeno. Em fumo, não foi observada reação típica de HR, havendo somente o amarelecimento da região infiltrada, após $24 \mathrm{~h}$. Os resultados indicaram que esta bactéria pertence ao patovar vignicola e tem somente o feijãocaupi como hospedeiro.

No processo de identificação do agente causal da doença foram determinadas as seguintes características: colônias mucóides, amareladas, convexas e de bordos regulares; bactéria Gram-negativa, 
aeróbia estrita, com resultado positivo para produção de xantomonadina, hidrólise do amido e aesculina, ácido a partir de arabinose e utilização de D-frutose, L-fucose, D-manose, manitol, melibiose, glicerol, glicose, sacarose e D-trealose, como fontes únicas de carbono e nitrogênio. Resultado negativo para: oxidase, urease, utilização de asparagina, dulcitol, arginina e sorbitol como fontes únicas de carbono e nitrogênio.

O conjunto de características permitiu identificar a bactéria Xanthomonas axonopodis pv. vignicola como agente causal da manchabacteriana $(10,7,12,17)$, sendo este o seu primeiro relato no estado de Roraima. $\mathrm{O}$ isolado se encontra depositado na coleção de Bactérias Fitopatogênicas do Instituto Biológico, Campinas, SP, com o código IBSBF 2412.

Os ensaios visando a reação de cultivares à doença revelaram haver reação diferencial à bactéria (Tabela 1 ). Em condições de casa-devegetação, o período de incubação foi de 8 a 11 dias, havendo maior severidade da doença nas cultivares BRS Amapá, Pitiúba, BR02Bragança e Patativa; todas com período de incubação de 8 dias. Nas cultivares BR17-Gurguéia e Vita-7 não foram observados sintomas da doença nestas condições (Tabela 1). A severidade da doença aos 25 dias após a inoculação variou de 1,3 a 12,5\%. Segundo Okechukwu \& Ekpo (14), valores menores que $10 \%$ indicam que a variedade é resistente, de 10 a 30 moderadamente suscetível e acima de $31 \%$ suscetível. Segundo este critério, as cultivares testadas não são consideradas suscetíveis e estão entre resistente e moderadamente suscetíveis. Entretanto, foi encontrada significativa diferença entre as variedades, em que BRS Amapá, Pitiúba, BR02-Bragança e BRS Patativa demonstraram serem as mais suscetíveis e BR17-Gurguéia, Vita-7 e BRS Mazagão com maior resistência à doença.

Em campo, o período de incubação foi menor que o observado em casa-de-vegetação, sendo reduzido em média em 2,8 dias (Tabela 1). As mesmas cultivares, classificadas como moderadamente suscetíveis em casa-de-vegetação, apresentaram significativamente maior suscetibilidade no ensaio de campo. Os maiores valores de severidade da doença no campo foram observados após 22-25 dias da inoculação (Figura 1). A cultivar BR02-Bragança foi a que apresentou maior AACPD da doença, seguido de BRS Amapá, BRS Patativa e Pitiúba (Tabela 1). As demais apresentaram menor intensidade da doença,

Tabela 1- Período de incubação em dias (PIcdv) e severidade (SEcdv) da mancha bacteriana aos 25 dias após a inoculação, em condições de casade-vegetação e período de incubação (PIcmp) e Área Abaixo da Curva de Progresso da Doença (AACPDcmp) em condições de campo, para dez cultivares de feijão-caupi.

\begin{tabular}{lccccc}
\hline Cultivar & Porte & PIcdv & SEcdv & PIcmp & AACPDcmp \\
\hline Amapá & Prostrado & $8 \mathrm{~B}$ & $12,5 \mathrm{~A}$ & $5,0 \mathrm{D}$ & $55,68 \mathrm{~B}$ \\
Bragança & Ereto & $8 \mathrm{~B}$ & $11,3 \mathrm{AB}$ & $5,5 \mathrm{D}$ & $105,8 \mathrm{~A}$ \\
Guariba & Ereto & $8 \mathrm{~B}$ & $2,5 \mathrm{BC}$ & $5,0 \mathrm{D}$ & $8,3 \mathrm{C}$ \\
Gurguéia & Prostrado & $*$ & $*$ & $9,5 \mathrm{AB}$ & $4,7 \mathrm{C}$ \\
Mazagão & Ereto & $11 \mathrm{~A}$ & $1,3 \mathrm{C}$ & $9,3 \mathrm{ABC}$ & $3,1 \mathrm{C}$ \\
Milênio & Prostrado & $11 \mathrm{~A}$ & $6,0 \mathrm{ABC}$ & $5,8 \mathrm{CD}$ & $8,4 \mathrm{C}$ \\
Patativa & Prostrado & $8 \mathrm{~B}$ & $11,3 \mathrm{AB}$ & $6,3 \mathrm{BCD}$ & $22,7 \mathrm{BC}$ \\
Pitiúba & Ereto & $8 \mathrm{~B}$ & $12,5 \mathrm{~A}$ & $6,0 \mathrm{BCD}$ & $23,7 \mathrm{BC}$ \\
Tracuateua & Prostrado & $8 \mathrm{~B}$ & $4,3 \mathrm{ABC}$ & $5,0 \mathrm{D}$ & $7,7 \mathrm{C}$ \\
Vita-7 & Ereto & $*$ & $*$ & $11,7 \mathrm{~A}$ & $2,9 \mathrm{C}$ \\
\hline
\end{tabular}

*Não foram observados sintomas da mancha-bacteriana. Médias seguidas por letras iguais, na coluna, não diferem entre si pelo teste de Tukey, a 5\% de probabilidade.



Figura 1- Severidade da mancha-bacteriana em dez cultivares de feijãocaupi após a inoculação em condições de campo por Xanthomonas axonopodis pv. vignicola,

sendo observados, nestas condições, sintomas da mancha-bacteriana nas cultivares BR17-Gurguéia e Vita-7 em baixa severidade, e com maiores períodos de incubação, assim como BRS Mazagão, confirmando sua resistência.

Dentre esses materiais as cultivares Vita-7 e BRS Mazagão (correspondente à linhagem IT87D-1627) são provenientes do IITA (International Institute of Tropical Agriculture) na Nigéria. Tem sido verificado que cultivares do grupo Vita apresentam resistência à manchabacteriana do feijão-caupi (1). A cultivar BR17-Gurguéia [obtida do cruzamento entre BR 10-Piauí e CE-315 (TVu 2331)] é de origem brasileira e pela primeira vez a resistência desse genótipo à doença é relatada.

Embora tenham ocorrido condições favoráveis de precipitação pluviométrica para o progresso e disseminação da doença no campo durante o período do experimento (Figura 2), não foram observadas vagens com sintomas da doença.

Não se verificou relação entre o porte das cultivares de feijãocaupi e resistência à mancha-bacteriana. Diferente do observado por Nechet et al. (13) em relação à reação de cultivares de feijão-caupi à mela em que houve uma tendência de genótipos de porte prostrado apresentarem menor severidade do que os de porte ereto.

Apesar da semente ser considerada uma importante fonte de inóculo (21) não foram verificadas colônias de X. axonopodis pv. vignicola associadas às sementes obtidas das plantas em cada parcela,



Figura 2- Precipitação após a inoculação da bactéria em experimento de campo. 
evidenciando a não ocorrência da transmissibilidade da bactéria, por meio de sementes, nas condições experimentais. Como citado anteriormente não foram observados sintomas em vagens o que pode ter contribuído para limitar a penetração do patógeno e consequentemente a infecção das sementes. Valladares-Sanchez et al. (19) observaram que plantas de feijão-comum com alta resistência de vagem à Xanthomonas axonopodis pv. phaseoli apresentavam reduzida infecção das sementes pelo patógeno. O resultado do presente trabalho leva a formulação de duas hipóteses a serem testadas: 1) para haver transmissibilidade do patógeno pelas sementes, a infecção deve ocorrer em estádio fenológico anterior à fase de emissão dos primeiros botões florais; 2) existe resistência diferencial à mancha-bacteriana entre folhas e vagens em acessos de feijão-caupi. A não correlação entre a resistência de folhas e vagens tem sido observada frequentemente no patossistema $X$. axonopodis pv. phaseoli var. fuscans e feijão-comum enfatizando a avaliação de ambas as reações como importantes na seleção de genótipos resistentes (9). Além disso, em condições experimentais a transmissibilidade da bactéria só foi observada quando houve inoculação artificial de sementes de feijão-caupi com a bactéria e o nível de transmissibilidade variou significativamente com a combinação isolado e variedade (15).

Vários trabalhos têm demonstrado diferentes níveis de reação em cultivares de feijão-caupi à X. axonopodis pv. vignicola $(14,18)$. Entretanto, para as cultivares desenvolvidas no Brasil os resultados apresentados neste trabalho são o primeiro registro da reação de resistência à mancha-bacteriana do feijão-caupi. Dentro de um programa de manejo integrado da doença, a indicação de cultivares resistentes é um método prático e de baixo custo para ser adotado pelo produtor. Além disso, gera informações para os programas de melhoramento que visam a identificação de progênies resistentes à doença.

\section{AGRADECIMENTOS}

O primeiro autor agradece ao $\mathrm{CNPq}$ pela concessão de bolsa, processo: 303081/2007-4.

\section{REFERÊNCIAS BIBLIOGRÁFICAS}

1. Allen, D. J.; Emechebe, A. M.; Ndimande, B. Identification of resistance in cowpea to diseases of the African savannas. Tropical Agriculture, Trinidade, v. 58, p. 26-74, 1981.

2. Campbell, C. L.; Madden, L. V. Introduction to plant disease epidemiology. New York: J.Wiley \& Sons, 1990. 532 p.

3. Ekpo, E. J. A. Effect of Xanthomonas vignicola on the yield of cowpea (Vigna unguiculata). African Journal of Agricultural Sciences, Addis Ababa, v. 5, n. 1 p. 67-69, 1978.

4. Freire filho, F. R.; Lima, J. A. A.; Ribeiro, V. Q. Feijão-caupi: avanços tecnológicos. Brasília: Embrapa Informação Tecnológica, 2005. 519 p.

5. James, W. C. An illustrated series of assessment keys for plant diseases, their preparation and usage. Canadian Plant Disease
Survey, Ottawa, v. 51, n.2, p.39-65, 1971.

6. Kado, C. I.; Heskett, M. G. Selective media for isolation of Agrobacterium, Corynebacterium, Erwinia, Pseudomonas and Xanthomonas. Phytopathology, St. Paul, v. 60, n. 6, p. 969-976, 1970.

7. Khatri-Chhetri, G. B.; Wydra, K.; Rudolph, K. Metabolic diversity of Xanthomonas axonopodis pv. vignicola, causal agent of cowpea bacterial blight and pustule. European Journal of Plant Pathology, Dordrecht, v. 109, n. 8, p. 851-860, 2003.

8. Kishun, R. Appraisal of loss in yield of cowpea due to Xanthomonas axonopodis pv. vignicola. Indian Phytopathology, New Delhi, v. 42, n. 1, p. 144-146, 1989

9. Kobayasti, L.; Souza, R. M.; Santos, J.B. Avaliação de cultivares e linhagens de feijoeiro quanto à reação foliar e de vagens à Xanthomonas axonopodis pv. phaseoli var. fuscans. Ciência e Agrotecnologia, Lavras, v. 23, n. 1, p. 40-47, 1999.

10. Leyns F.; De Cleene, M.; Swings, J.; De Ley, J. The rost range of the genus Xanthomonas. The Botanical Review, Lancaster, v. 50, n. 3, p. 308-355, 1984.

11. Marques, A. S. A.; Robbs, C. F.; Boiteux, L.S.; Parente, P. M. G. Índice de Fitobacterioses assinaladas no Brasil. Brasília: Embrapa-SPI, 1994. 65p.

12. Moretti, C.; Mondjana, A. M.; Zazzerini, A.; Buonaurio, R. Occurrence of leaf spot on cowpea (Vigna unguiculata) caused by Xanthomonas axonopodis pv. vignicola in Mozambique. Plant Pathology, Oxford, v. 56, n. 2, p. 347, 2007.

13. Nechet, K. L.; Halfeld-Vieira, B. A. Reação de cultivares de feijão-caupi à mela (Rhizoctonia solani) em Roraima. Fitopatologia Brasileira, Lavras, v. 32, n. 5, p. 424-428, 2007.

14. Okechukwu, R.U.; Ekpo, E.J.A. Sources of resistance to cowpea bacterial blight disease in Nigeria. Journal of Phytopathology, Berlin, v. 152, n. 6, p. 345-351, 2004.

15. Okechukwu, R.U.; Ekpo, E.J.A.; Okechukwu, O.C. Seed to plant transmission of Xanthomonas campestris pv. vignicola isolates in cowpea. African Journal of Agricultural Research, Victoria Island, v.5, n.6, p. 431-435, 2010.

16. Patel, P.N. Pathogen variability and host resistance in bacterial pustule disease of cowpea in Africa. Tropical Agriculture, Coronado, v. 58, n. 3, p. 275-280, 1981.

17. Schaad, N.W.; Jones, J.B.; Chun, W. (Ed.). Laboratory guide for identification of plant pathogenic bacteria. Saint Paul: APS Press, 2001. 373 p.

18. Srivastava, S.S.L.; Biswas, S.K. Evaluation of cowpea cultivars for resistance against Xanthomonas axonopodis pv. vignicola. Annals of Plant Protection Science, New Delhi, v. 14, n. 2, p. $508,2006$.

19. Valladares-Sanchez, N. E.; Coyne, D. P.; Mumm, R. F. Inheritance and associations of leaf, external, and internal pod reactions to commom blight bacterium in Phaseolus vulgaris L. Journal of the American Society for Horticultural Science, Saint Paul, v.108, n.2, p.272-278, 1983.

20. Verdier, V.; Assigbétsé, K.; Khatri-Chhetri, G.; Wydra, K.; Rudolph, K.; Geiger, J.P. Molecular characterization of the incitant of cowpea bacterial blight and pustule, Xanthomonas axonopodis pv. vignicola. European Journal of Plant Pathology, Dordrecht, v. 104, n. 6 , p. 595-602, 1998

21. Wydra, K.; Khatri-Chhetri, G.; Mavridis, A.; Sikirou, R.; Rudolph, K. A. diagnostic medium for the semi-selective isolation and enumeration of Xanthomonas axonopodis pv. vignicola. European Journal of Plant Pathology, Dordrecht, v. 110, n. 10, p. 9911001,2004 